\title{
Use of Steroids in Treatment of Aphthous Ulceration
}

\author{
I. T. MACPHEE, ${ }^{*}$ B.D.S., F.D.S. R.C.S.ED. ; W. SIRCUS, $\dagger$ M.D., PH.D., F.R.C.P., F.R.C.P.ED. \\ E. D. FARMER, $\ddagger$ M.A., M.D.S., F.D.S. R.C.S., M.C.PATH. ; R. A. HARKNESS,§ M.B., CH.B., PH.D., M.R.C.P.ED. \\ G. C. COWLEY,\| D.D.S.
}

Statistical Analysis by S. A. SKLAROFf, B B.SC.

Brit. med. F., 1968, 2, 147-149

There is as yet no real information about the prevalence of aphthous ulceration in the general population. In a sample of 1,500 consecutive hospital outpatients it was estimated that one out of every five at some period of their life suffered from this form of mouth ulceration (Sircus et al., 1957). In a survey of a professional school population carried out by Ship et al. (1960) a prevalence of about $54 \%$ was recorded, and in a further study of a student body the prevalence was $66 \%$ (Ship et al., 1967).

The cause of aphthous ulceration is unknown, so that methods of treatment have been entirely empirical. It has been suggested that benefit to the patient may follow the use of antibiotics (Zegarelli et al., 1952; Sircus et al., 1957), viral vaccines (Woodburne, 1941), gammaglobulin (Fraser-Moodie, 1960), quinoline derivatives (Natarajan, 1964), mucosal protectants (Barile and Grayskowski, 1963), corticosteroids (Truelove and Morris-Owen, 1958; Sircus, 1959; Cooke and Armitage, 1960), oestrogens (Bishop et al., 1967), and antiseptic, anaesthetic, or analgesic preparations too numerous to recount.

The disease has a natural rhythm of exacerbation and spontaneous remission which complicates any assessment of the true value of treatment (Sircus, 1959), and in general it is difficult to decide to what extent the benefit which has been claimed to follow the use of these preparations exists in fact, as against being the subjective impressions of the clinicians who prescribed them or of the patients who received them.

On the basis of such information as is available from controlled studies it seems that the most promising approach to treatment lies in the administration of a small dose of corticosteroids. After a controlled trial with $2.5-\mathrm{mg}$. tablets of hydrocortisone hemisuccinate (Corlan pellets), Cooke and Armitage (1960) stated: "When considering all the patients together the degree of ulceration was reduced by about $50 \%$," during the period of the trial, "and the reduction could often be maintained for three to six months" thereafter.

\section{Pilot Study}

A double-blind pilot study was designed in Edinburgh to investigate the effects of triamcinolone acetonide (Adcortyl-A in Orabase) and hydroxyquinoline on a group of 17 patients with severe continuous aphthous ulceration, no patient having been free of ulceration for more than seven days during the previous six months. Orabase (an ointment containing carboxymethylcellulose), which is the vehicle used for the administration of the proprietary preparation of triamcinolone, was included to serve as control for this preparation. Lactose pellets

\footnotetext{
- Senior Lecturer, Department of Periodontology, Edinburgh Dental School.

+ Gastrointestinal Unit and Department of Medicine, Western General Hospital, Edinburgh. M.R.C. External Staff.

₹ Louis Cohen Professor of Dental Surgery, Department of Dental Surgery, University of Liverpool.

5 Senior Lecturer, Department of Clinical Chemistry, University of Edinburgh.

were made up in a form identical with the hydroxyquinoline tablets. The order of administration was randomized and the drugs were taken by the patients in direct sequence during four continuous 28-day periods with no intervening control periods. Patients were supplied with specially prepared diaries in which to record the incidence and duration of each ulcer during the entire four-month period.

The dosage of drugs employed was: triamcinolone applied to existing lesions four times a day, providing a dose which has been calculated in similar circumstances to be from 0.24 to $1 \mathrm{mg} . /$ day (Zegarelli et al., 1959) ; Orabase applied to existing lesions four times a day; one $0.65-\mathrm{mg}$. tablet of hydroxyquinoline swallowed three times a day whether the lesions were present or not.

Only 8 of the 17 patients completely fulfilled the conditions of the trial for the four-month period, and the results are shown in Tables I and II. Total new ulcers (Table I) is a measure of the incidence of ulceration within the trial period. The mean number of new ulcers occurring in relation to each treatment was remarkably consistent, and the analysis of variance confirms that the differences between the treatments are not significant. Similarly, the total number of new ulcer days is an index of the duration of new ulcers occurring within the trial period (Table II). The mean duration of ulcers ranged from 60 to 73 days, and analysis of variance showed that differences between the treatments are not significant. These findings were independent of the drug-placebo order. With respect to steroids the results indicated that triamcinolone given over a period of four weeks in the dose range used was unlikely to be effective against aphthous ulceration of the degree of severity selected for the trial.

Table I.-1963 Pilot Study, Number of New Ulcers per 28-Day Period

\begin{tabular}{c|c|c|c|c}
\hline \begin{tabular}{c|c|c} 
Case \\
No.
\end{tabular} & Lactose & Orabase & $\begin{array}{c}\text { Hydroxy- } \\
\text { quinoline }\end{array}$ & Triamcinolone \\
\hline 1 & 7.00 & 8.69 & 10.08 & 6.79 \\
2 & 17.63 & 3.73 & 17.63 & 10.62 \\
3 & 8.00 & 9.03 & 7.23 & 10.00 \\
4 & 7.00 & 8.13 & 5.09 & 8.00 \\
5 & 9.66 & 10.96 & 6.00 & 8.30 \\
6 & 6.53 & 5.42 & 8.00 & 4.52 \\
7 & 1.04 & 6.76 & 5.00 & 7.72 \\
8 & 5.83 & 6.46 & 5.60 & 10.18 \\
\hline Mean & 7.84 & 7.40 & 8.08 & 8.27 \\
\hline
\end{tabular}

Analysis of variance: differences between treatment not significant at the $10 \%$ level.

\begin{tabular}{|c|c|c|c|c|}
\hline $\begin{array}{l}\text { Case } \\
\text { No. }\end{array}$ & Lactose & Orabase & $\begin{array}{l}\text { Hydroxy- } \\
\text { quinoline }\end{array}$ & Triamcinolone \\
\hline $\begin{array}{l}1 \\
2 \\
3 \\
4 \\
5 \\
6 \\
7 \\
8\end{array}$ & $\begin{array}{r}67.00 \\
128.59 \\
108.00 \\
73.00 \\
110.07 \\
45.73 \\
7.26 \\
46.67\end{array}$ & $\begin{array}{r}44.41 \\
23.33 \\
56.00 \\
97.55 \\
116.87 \\
23.48 \\
64.69 \\
60.31\end{array}$ & $\begin{array}{r}62.72 \\
110.96 \\
63.23 \\
57.70 \\
55.00 \\
56.00 \\
41.00 \\
80.64\end{array}$ & $\begin{array}{r}38 \cdot 18 \\
78 \cdot 21 \\
69 \cdot 00 \\
100 \cdot 00 \\
64 \cdot 30 \\
13 \cdot 55 \\
77 \cdot 24 \\
124 \cdot 73\end{array}$ \\
\hline Mean & 73.29 & 60.83 & 65.91 & 70.65 \\
\hline
\end{tabular}
Analysis of variance: differences between treatment not significant at the $10 \%$
level. 


\section{Trial Design}

At a meeting of the consultants in charge of four centres in different parts of the country it was decided to co-operate in a therapeutic trial to overcome the problem of patient fall-out and the difficulty of assessing therapeutic effects in cyclic disorders. The treatments to be investigated were local application of Orabase and triamcinolone as in the pilot study, systemic betamethasone disodium phosphate (Beta-Corlan), the tablets being swallowed ; local betamethasone, the tablets being allowed to dissolve slowly in the mouth; and Biobase (carbenoxolone sodium in a bland adhesive vehicle). Each patient followed a sequence of two drugs over a four-month period, with a blank month intervening and a blank month following. The dosages used were: triamcinolone and Orabase applied to existing lesions four times daily to a calculated range of dosage of 0.24 to $1 \mathrm{mg}$. ; Orabase applied to existing lesions four times a day; betamethasone, one $0.1-\mathrm{mg}$. tablet allowed to dissolve slowly in the mouth four times a day whether lesions were present or not; one betamethasone $0.1-\mathrm{mg}$. tablet swallowed four times a day whether the lesions were present or not; and carbenoxolone applied to existing lesions four times a day. The amount of triamcinolone used was dependent on the frequency and duration of the ulceration. The dosage of betamethasone was constant whether the patient had ulcers or not, and can be regarded as a maintenance dose of $0.4 \mathrm{mg}$./day, over 28 days, given by different routes of absorption.

Early in the trial two of the consultants became concerned with the potential risks of the administration of steroids to patients and withdrew, though search of the literature revealed no direct evidence that with a total dose which ranged from 0.24 to $1 \mathrm{mg}$. of triamcinolone or $0.4 \mathrm{mg}$. of betamethasone daily such risks existed. The units in Edinburgh and Liverpool elected to continue the trial until it was just possible to reach a statistically valid conclusion, but arrangements were made to investigate the effect on adrenocortical function of $0.4 \mathrm{mg}$. of betamethasone daily allowed to dissolve in the mouth. When it became clear that this dosage of betamethasone could have a greater systemic effect than had been previously appreciated, by general agreement the trial was stopped. At this stage 80 patients had been accepted for treatment in Liverpool and Edinburgh, 31 had completely fulfilled the conditions of the trial, and one further patient had completed a full comparison for carbenoxolone alone. This patient has been included in the analysis. The ulceration in all the 31 patients fell within group 1 and group 3 aphthae (Kramer, 1965), with the exception of one patient who also had infrequent vaginal ulceration. The distribution of these patients with regard to sex and severity of ulceration in the six months before the trial is shown in Table III. With regard to duration of symptoms, more than half the patients had had the disease for five years or more, and one-third for 10 years or more.

TABLE III.-Number of Patients According to Severity in Six Monihs Before 1965 Trial
Babe 111.-Number of Patients According

\begin{tabular}{|c|c|c|c|}
\hline & Men & Women & Total \\
\hline $\begin{array}{l}30 \text { or more days without ulceration... } \\
\text { Less than } 30 \text { but more than seven days without }\end{array}$ & 5 & 7 & 12 \\
\hline 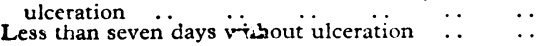 & $\begin{array}{l}9 \\
1\end{array}$ & $\begin{array}{l}6 \\
3\end{array}$ & $\begin{array}{r}15 \\
4\end{array}$ \\
\hline Total & 15 & 16 & 31 \\
\hline
\end{tabular}

\section{Results}

At the time the trial was stopped the patients were fairly evenly distributed with regard to the treatments (Table IV). The average number of new ulcers per month is a measure of the incidence of ulceration in the month of treatment as against the control month. The figures are remarkably consistent, the differences between the treatment and control months are small, and none approach statistical significance $(P>0.05)$.
TABl.E IV.-1965 Trial. Average Number of New Ulcers per Month per

\begin{tabular}{|c|c|c|c|c|c|}
\hline Treatment & $\begin{array}{l}\text { No. of } \\
\text { Patients }\end{array}$ & $\begin{array}{c}\text { Month } \\
\text { of } \\
\text { Treatment }\end{array}$ & $\mid \begin{array}{c}\text { Month } \\
\text { Without } \\
\text { Treatment }\end{array}$ & Diff. & S.E. \\
\hline $\begin{array}{l}\text { Orabase } \ldots \\
\text { Triamcinolone } \\
\text { Systemic beta- }\end{array}$ & $\begin{array}{l}11 \\
14\end{array}$ & $\begin{array}{l}3 \cdot 27 \\
2 \cdot 57\end{array}$ & $\begin{array}{l}2 \cdot 73 \\
2 \cdot 79\end{array}$ & $\begin{array}{l}+0.54 \\
-0.22\end{array}$ & $\begin{array}{l} \pm 0.49 \\
\pm 0.55\end{array}$ \\
\hline $\begin{array}{l}\text { methasone } \\
\text { Local betamethasone } \\
\text { Carbenoxolone } \quad .\end{array}$ & $\begin{array}{l}12 \\
12 \\
14\end{array}$ & $\begin{array}{l}5 \cdot 08 \\
3 \cdot 31 \\
2 \cdot 64\end{array}$ & $\begin{array}{l}4.41 \\
4.00 \\
3.50\end{array}$ & $\begin{array}{l}+0.67 \\
-0.69 \\
-0.86\end{array}$ & $\begin{array}{l} \pm 0.78 \\
\pm 1.61 \\
\pm 0.64\end{array}$ \\
\hline
\end{tabular}

The average number of new ulcer days per month (Table $\mathrm{V}$ ) is a measure of the duration of new ulcers occurring within the trial period. The differences are again fairly small and none approach statistical significance $(P>0.05)$. Similarly, analysis of total ulcer days (Table VI), including those ulcers which were present at the beginning of the treatment period, shows no significant difference. Separating out the old ulcers existing at the beginning of the trial gives the same result. The results for individual months were remarkably variable on any of the criteria, none of the differences being significant $(P>0.05)$. Overall there is no statistically demonstrable evidence that any of the treatments altered either the incidence or the duration of ulceration during the period of the trial. These findings are independent of the treatment/control order.

Table V.-1965 Trial. Average Number of New Ulcer Days per Month per Patient

\begin{tabular}{|c|c|c|c|c|c|}
\hline Treatment & $\begin{array}{c}\text { No. of } \\
\text { Patients }\end{array}$ & $\begin{array}{c}\text { Month } \\
\text { of } \\
\text { Treatment }\end{array}$ & \begin{tabular}{|c|} 
Month \\
Without \\
Treatment
\end{tabular} & Diff. & S.E. \\
\hline \multirow{2}{*}{$\begin{array}{l}\text { Orabase } \\
\text { Triamcinolone } \\
\begin{array}{l}\text { Systemic beta- } \\
\text { methasone }\end{array} \\
\text { Local betamethasone } \\
\text { Carbenoxolone .. }\end{array}$} & $\begin{array}{l}11 \\
14\end{array}$ & $\begin{array}{l}27 \cdot 54 \\
16 \cdot 50\end{array}$ & $\begin{array}{l}24.45 \\
21.07\end{array}$ & $\begin{array}{l}+3.09 \\
-4.57\end{array}$ & $\begin{array}{l} \pm 3.44 \\
\pm 4.30\end{array}$ \\
\hline & $\begin{array}{l}12 \\
12 \\
14\end{array}$ & $\begin{array}{l}41.08 \\
19 \cdot 69 \\
17 \cdot 79\end{array}$ & $\begin{array}{l}34 \cdot 83 \\
20 \cdot 38 \\
22 \cdot 00\end{array}$ & $\begin{array}{l}+6.25 \\
-0.69 \\
-4.21\end{array}$ & $\begin{array}{r} \pm 7.62 \\
\pm 10.75 \\
\pm 5.18\end{array}$ \\
\hline
\end{tabular}

TABLE VI.-1965 Trial. Average Number of Ulcer Days per Month per Patient

\begin{tabular}{|c|c|c|c|c|c|}
\hline Treatment & $\begin{array}{l}\text { No. of } \\
\text { Patients }\end{array}$ & $\begin{array}{c}\text { Month } \\
\text { of } \\
\text { Treatment }\end{array}$ & $\begin{array}{c}\text { Month } \\
\text { Without } \\
\text { Treatment }\end{array}$ & Diff. & S.E. \\
\hline \multirow{2}{*}{$\begin{array}{l}\text { Orabase . } \\
\text { Triamcinolone } \\
\text { Systemic beta- } \\
\text { methasone } \\
\text { Local betamethasone } \\
\text { Carbenoxolone }\end{array}$} & $\begin{array}{l}11 \\
14\end{array}$ & $\begin{array}{l}30 \cdot 73 \\
24 \cdot 50\end{array}$ & $\begin{array}{l}29 \cdot 46 \\
21.86\end{array}$ & $\begin{array}{l}+1 \cdot 27 \\
+2 \cdot 64\end{array}$ & $\begin{array}{l} \pm 2.06 \\
\pm 4.49\end{array}$ \\
\hline & $\begin{array}{l}12 \\
12 \\
14\end{array}$ & $\begin{array}{l}56 \cdot 1 \\
23.46 \\
28 \cdot 21\end{array}$ & $\begin{array}{l}48 \cdot 6 \\
24 \cdot 40 \\
31 \cdot 57\end{array}$ & $\begin{array}{l}+7.5 \\
-0.94 \\
-3.36\end{array}$ & $\begin{array}{r} \pm 8.20 \\
\pm 11.09 \\
\pm 4.89\end{array}$ \\
\hline
\end{tabular}

\section{Discussion}

These findings conflict sharply with Cooke and Armitage's (1960) results in which hydrocortisone pellets were administered over an eight-week period. It seemed possible that any beneficial effect may not show until the patient has been taking the drug for a minimum period in excess of four weeks.

When the results of the present trial are standardized to an eight-week period (Table VII), the figures for incidence of new ulcers are similar to those of Cooke and Armitage in both treatment and untreated periods.

The figures of duration of ulceration are similar to those of Cooke and Armitage only for the periods without treatment.

The extended figures of the present trial (to an equivalent eight-week period) indicate a reduction of the duration of

TABLE VII.-Comparison of Cooke and Armituge (1950) Results with Hydrocortisone (2.5 mg.) with Present Trial of Betamethasone (0.1 mg.) Equivalent Eight Week Period

\begin{tabular}{|c|c|c|c|c|}
\hline & \multicolumn{2}{|c|}{ Total Ulcer Days } & \multicolumn{2}{|c|}{ New Ulcer } \\
\hline & Treated & Untreated & Treated & Untreated \\
\hline $\begin{array}{l}\text { Local betamethasone (present } \\
\text { trial ... }\end{array}$ & $46 \cdot 9$ & $61 \cdot 5$ & $5 \cdot 2$ & $7 \cdot 1$ \\
\hline $\begin{array}{c}\text { Hydrocortisone (Cooke and } \\
\text { Armitage, 1960) }\end{array}$ & $26 \cdot 3$ & $65 \cdot 9$ & $4 \cdot 1$ & $9 \cdot 0$ \\
\hline
\end{tabular}


ulceration after the use of betamethasone of $28 \%$, compared with the figure of $50 \%$ reduction with hydrocortisone pellets reported by Cooke and Armitage.

It is not possible to make a proper statistical comparison from such extended figures, but it is of interest that the change, though insignificant statistically, is in the same direction. Since the drug doses are equivalent, one explanation of the difference between the two sets of results may lie in the different duration of treatment-four weeks as against eight weeks. It is possible that the effect may not show until the patient has been taking the drug for a minimum period in excess of four weeks.

A further explanation is suggested by a Bartlett test of homogeneity of variance which was significant over the five treatments $(\mathrm{P}<0.01)$. The largest variance was associated with the use of betamethasone allowed to dissolve in the mouth. This suggests the possibility that there may be "interaction" between effectiveness of the steroid and type of patient.

The question arises whether the evidence of benefit is suffisiently clear-cut to justify the prolonged use of steroids for treatment of aphthous ulceration and to compensate for any risk to the patient which may exist at the suggested level of dosage. The estimated minimum dose producing marked adrenal suppression is held to be of the order of $50 \mathrm{mg}$. of hydrocortisone or equivalent daily (Lehner, 1967), and this level of dosage is not reached by any of the steroid preparations used in the mouth $(0.4 \mathrm{mg}$. of betamethasone is the equivalent of $14 \mathrm{mg}$. of hydrocortisone).

During the course of the trial the effect on adrenal cortical function of sublingual doses of $0.4 \mathrm{mg}$. of betamethasone daily was investigated by measuring urinary levels of metabolites of

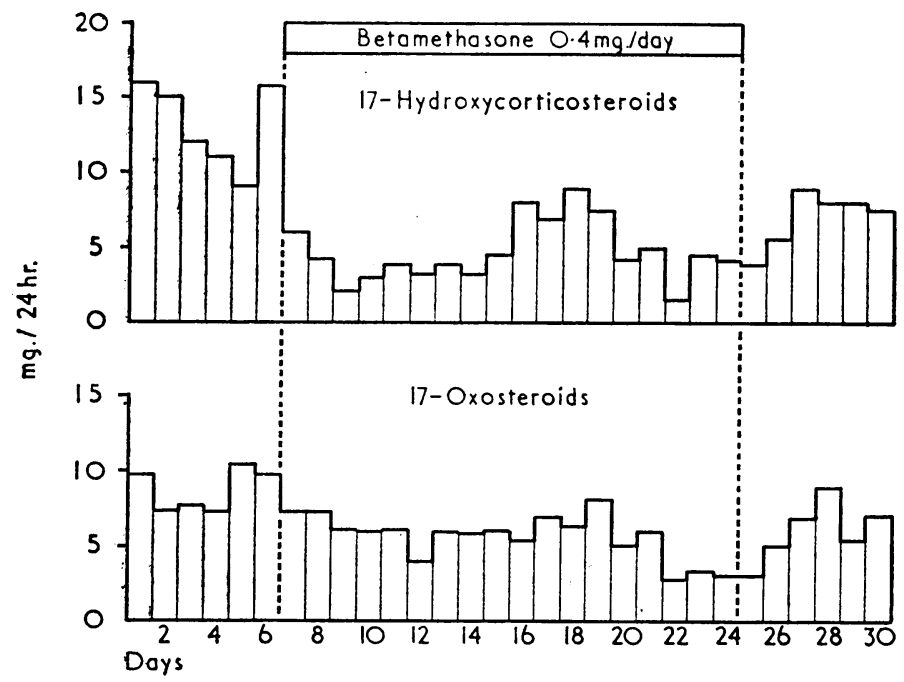

Effect of betamethasone on level of 17-hydroxycorticosteroids 17-oxosteroids in a man aged 47 .

adrenal cortical hormones (17-hydroxycorticosteroids). Complete 24-hour samples of urine were collected by one man for 30 days. The urinary levels of 17-hydroxycorticosteroids and 17-oxosteroids were determined by the methods of Appleby et al. (1955) and Vestergaard (1951) respectively. For 18 days -from the seventh to the twenty-fourth day of the study0.1-mg. pellets of betamethasone were dissolved slowly in the mouth four times daily at regular intervals. The levels of 17hydroxycorticosteroids and 17-oxosteroids during the initial control period were within the normal range, though showing the effect of adaptation to the problems of urine collection by an initial fall (see Chart). During treatment the output of 17hydroxycorticosteroids fell and remained at the lower limit of the normal range except for days 15-19 inclusive, when an increase in output occurred, and coinciding with a period of severe psychological stress in the subject. After the end of the treatment, levels rose again and remained steady. Similar but less marked changes occurred in the excretion of 17-oxosteroids.

This investigation indicates that depression of adrenal cortical function can occur as a consequence of daily treatment with $0.4 \mathrm{mg}$. of betamethasone. The presence in the circulation of the synthetic analogue of the natural hormone would lead, by way of the sensory and regulatory mechanisms, to lowering of the levels of the natural hormone. However, the rise in urinary 17-hydroxycorticosteroids on days 15-19 in the subject as described above, and the results of a similar phenomenon observed in a second study in another healthy man, show that in response to stress an increase in adrenal cortical activity can still occur during such periods of treatment.

Betamethasone 17-valerate may be safer in that $4 \mathrm{mg}$./day did not suppress adrenal function in a colitis trial (Friedman et al., 1967).

While several studies indicate that a proportion of patients treated with low dosages of steroids show inadequate response to stimulation of the mechanisms controlling the hypothalamopituitary-adrenal axis, what is uncertain is the significance of such phenomena in the context of the clinical response of the patient to stress such as by surgical trauma (Scoggins and Kliman, 1965 ; Jasani et al., 1967 ; Otaki, 1967).

\section{Summary}

There is no evidence of alteration of incidence or duration of aphthous ulceration following the use of triamcinolone acetonide (Adcortyl-A in Orabase), Orabase, hydroxyquinoline, carbenoxolone sodium (Biobase), or betamethasone disodium phosphate (Beta-Corlan), for a period of four weeks.

Depression of the hypothalamo-pituitary-adrenal axis can follow sublingual absorption of $0.4 \mathrm{mg}$. of betamethasone daily.

There is a need for study of morbidity and mortality arising in patient populations on long-term treatment with small doses of corticosteroids.

We are indebted to Dr. G. P. Crean, of the Clinical Endocrinology Research Unit, Edinburgh, for his helpful advice in respect of the steroid study. We would further express our appreciation to Squibb and Sons Ltd., who provided the Adcortyl-A in Orabase and the Orabase ; to Glaxo Laboratories Ltd., who provided the Beta-Corlan and placebo tablets ; and to Berk Pharmaceuticals Ltd., who provided the Biobase. The study was financed by a grant from the Squibb Institute. We are obliged to Mrs. Elspeth Semple for arranging the packing and issue of drugs according to the trial design, and to Miss Maureen Brown, who helped in the machine analysis of the records.

\section{REFERENCES}

Appleby, J. I., Gibson, G., Norymberski, J. K., and Stubbs, R. B. (1955). Biochem. F., 60, 453 .

Barile, M. F., and Grayskowski, E. A. (1963). F. Dist. Columbia dent. Soc., 38,7 .

Bishop, P. M. F., Harris, P. W. R., and Trafford, J. A. P. (1967). Lancet, 1,1345 .

Cooke, B. E. D., and Armitage, P. (1960). Brit. med. 7., 1, 764

Fraser-Moodie, W. (1960). Brit. dent. F., 108, 326.

Friedman, M., Fletcher J., Hinton, J., M., 326. Lennard-Jones, J. E Misiewicz, J. J., and Parrish, J. A. (1967). Brit. med. F., 1, 335 . Jasani, M. K., et al.' (1967). Quart. F. Med., 36, 261.

Kramer, I. R. H. (1965). Proc. roy. Soc. Med., 58, 458.

Lehner, T. (1967). Brit. dent. $\dot{f}$., 122, 15.

Natarajan, R. (1964). Lancet, 1, 830.

Otaki, A. T. (1967). Personal communication to Dr. Sircus.

Scoggins, R. B., and Kliman, B. (1965). New Engl, f. Med, 273, 831.

Ship, I. I., Morris, A. L., Durocher, R. T., and Burket, L. W. (1960) Oral Surg., 13, 1191.

Ship, I. I., Brightman, V. J., and Laster, L. L. (1967). F. Amer. dent. Ass., 75, 645.

Sircus, W. W. (1959). Brit. med. 7., 2, 804.

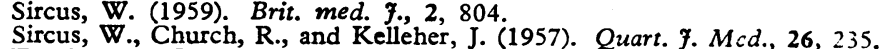

Truelove, S. C., and Morris-Owen, R. M. (1958). Brit. med. F., 1, 603.

Vestergaard, P.' (1951). Acta endocr. (Kbh.), 8, 193.

Woodburne, A. R. (1941). Arch. Derm. Syph. (Chic.), 43, 543.

Zegarelli, E. V., Silvers, H. F., and Kutscher, A. H. (1952). N.Y. St. dent. F., 18, 137.

Zegarelli, E. V., Kutscher, A. H., and Silvers, H. F. (1959). F. Periodont., 30, 63. 